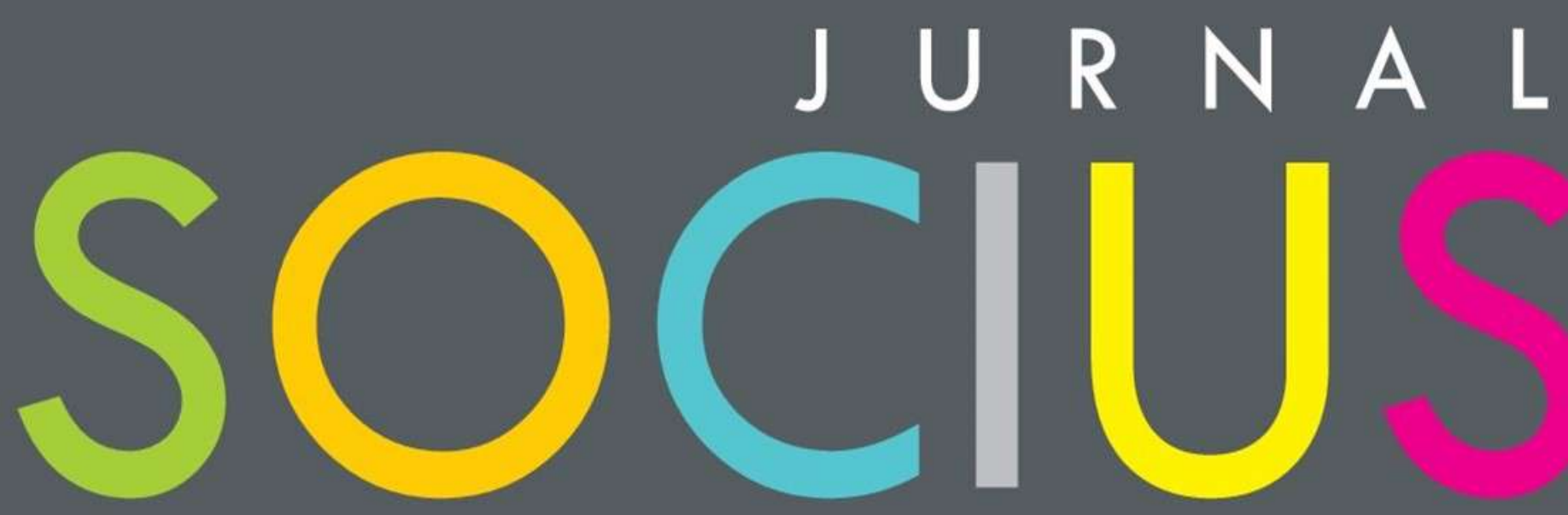

Journal of Sociology Research and Education

DITERBITKAN OLEH :

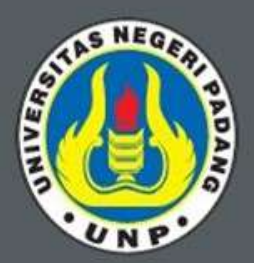

LABOR

JURUSAN SOSIOLOGI

FAKULTAS ILMU SOSIAL

UNIVERSITAS NEGERI PADANG

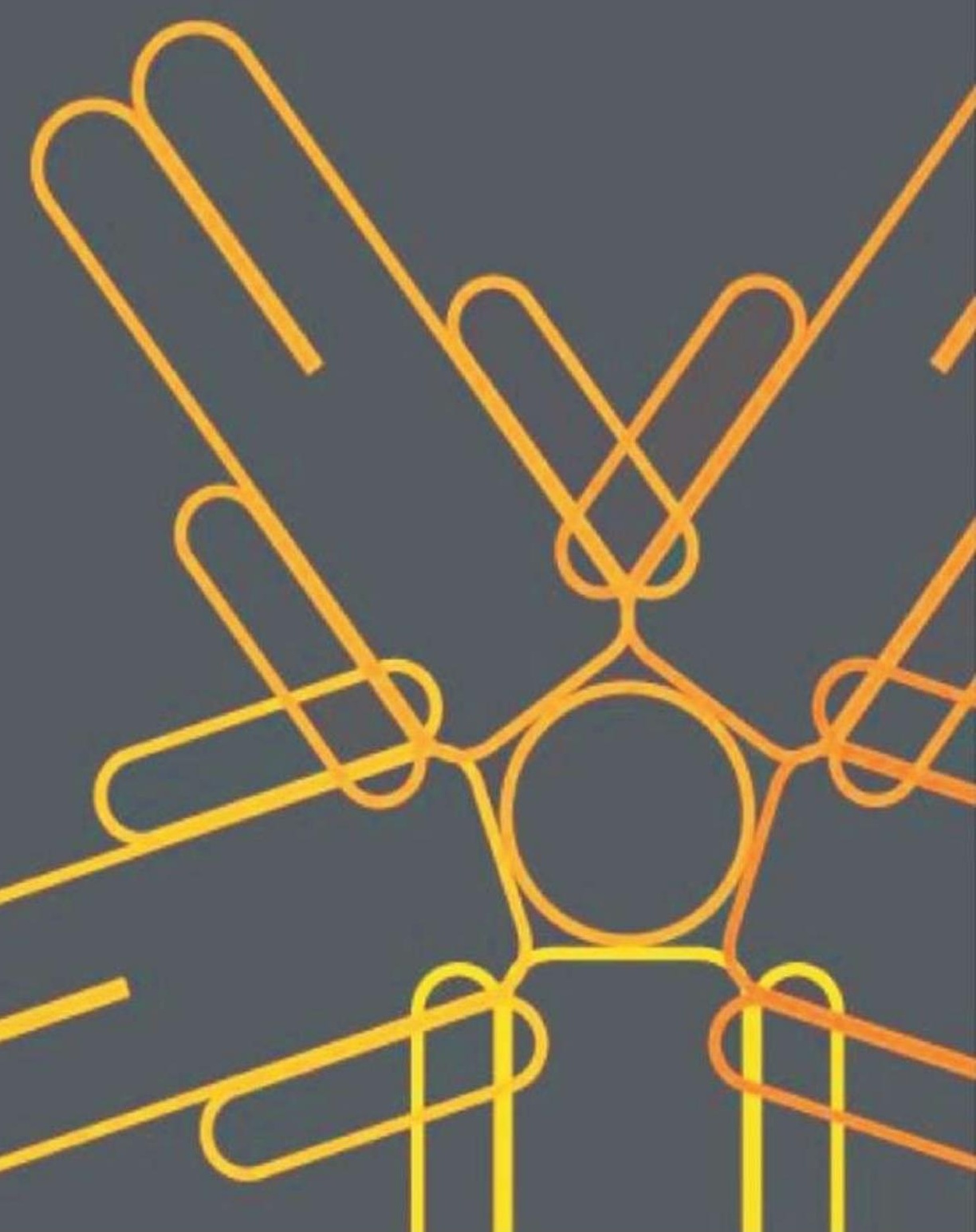




\section{SOCIUS}

Vol. 8, No. 1, Th. 2021

ISSN : 2356-4180 (cetak)

2442-8663 (online)

\begin{tabular}{|c|c|}
\hline $\begin{array}{c}\text { REDAKSI } \\
\text { JURNAL SOCIUS }\end{array}$ & DAFTAR ISI \\
\hline $\begin{array}{l}\text { Editor in Chief : } \\
\text { Desy Mardhiah } \\
\text { (Universitas Negeri Padang) }\end{array}$ & $\begin{array}{c}\text { Arni Darmayanti, Gede Budarsa } \\
\text { Peran Ganda Perempuan Bali di Masa Pandemi Covid-19 } \\
\text { Halaman 1-12 }\end{array}$ \\
\hline $\begin{array}{l}\text { Managing Editor : } \\
\text { Erda Fitriani } \\
\text { (Universitas Negeri Padang) }\end{array}$ & $\begin{array}{c}\text { Luthfi Hasanal Bolqiah, Riaty Raffiuddin } \\
\text { Dominasi Oligarki dalam Pembangunan Reklamasi Pantai Utara Jakarta } \\
\text { Halaman 13-25 }\end{array}$ \\
\hline $\begin{array}{l}\text { Editorial Board: } \\
\text { Elfitra Baikoeni } \\
\text { (Universitas Andalas) }\end{array}$ & $\begin{array}{c}\text { Rinel Fitlayeni, Ikhsan Muharma Putra, Marleni Marleni, } \\
\text { Elvawati Elvawati, Winda Sri Yulia Putri }\end{array}$ \\
\hline $\begin{array}{c}\text { Iskandar } \\
\text { (Universitas Trunojoyo) }\end{array}$ & $\begin{array}{c}\text { Penguatan Kapasitas Pedagang dalam Resolusi Konflik Asimetris di } \\
\text { Pasar Raya Padang Pasca Gempa }\end{array}$ \\
\hline $\begin{array}{c}\text { Ike Sylvia } \\
\text { (Universitas Negeri Padang) }\end{array}$ & Halaman 26-35 \\
\hline $\begin{array}{c}\text { Erianjoni } \\
\text { (Universitas Negeri Padang) } \\
\text { Emizal Amri } \\
\text { (Universitas Negeri Padang) }\end{array}$ & $\begin{array}{c}\text { Dahlia Morina Hutagalung, Ferdinand Kerebungu, Maryam } \\
\text { Lamadirisi } \\
\text { Perilaku Belajar Mahasiswa Batak Toba di Universitas Negeri Manado } \\
\text { Halaman 36-46 }\end{array}$ \\
\hline $\begin{array}{l}\text { Mohammad Isa Gautama } \\
\text { (Universitas Negeri Padang) }\end{array}$ & $\begin{array}{c}\text { Rifqi Asy'ari, Rusdin Tahir, Cecep Ucu Rakhman, Rifki } \\
\text { Rahmanda Putra }\end{array}$ \\
\hline $\begin{array}{l}\text { Khairul Fahmi } \\
\text { (Universitas Negeri Padang) }\end{array}$ & $\begin{array}{l}\text { Pengembangan Pariwisata Berbasis Masyarakat di Provinsi Jawa Barat } \\
\text { Halaman 47-58 }\end{array}$ \\
\hline $\begin{array}{c}\text { Reno Fernandes } \\
\text { (Universitas Negeri Padang) }\end{array}$ & $\begin{array}{c}\text { Reno Fernandes, Azwar Ananda, Maria Montessori, Firman } \\
\text { Firman, Eka Vidya Putra, Hendra Naldi, Erda Fitriani }\end{array}$ \\
\hline $\begin{array}{c}\text { Layout Editor: } \\
\text { Rhavy Ferdyan } \\
\text { Technical Support: } \\
\text { Rudi Mahesa }\end{array}$ & $\begin{array}{c}\text { Adaptasi Dosen Digital Immigrant Terhadap Pelaksanaan Pembelajaran } \\
\text { pada Masa Pandemi Covid-19 } \\
\text { Halaman 59-72 }\end{array}$ \\
\hline $\begin{array}{c}\text { Alamat Redaksi: } \\
\text { Jurusan Sosiologi FIS UNP } \\
\text { Jl. Prof.Dr.Hamka } \\
\text { Kampus UNP Air Tawar } \\
\text { e-mail: socius@ppj.unp.ac.id }\end{array}$ & \\
\hline $\begin{array}{l}\text { Penerbit } \\
\text { Labor Jurusan Sosiologi } \\
\text { Universitas Negeri Padang }\end{array}$ & \\
\hline
\end{tabular}




\title{
Peran Ganda Perempuan Bali di Masa Pandemi Covid-19
}

\author{
Arni Darmayanti ${ }^{1}$, Gede Budarsa ${ }^{2}$ \\ ${ }^{1,2}$ Universitas Udayana \\ Email: arnidarmayanti11@gmail.com
}

\begin{abstract}
Abstrak
Pandemi Covid-19 berefek pada perekonomian Bali yang mengandalkan sektor pariwisata. Turunnya tingkat kunjungan wisatawan ke Bali berpengaruh terhadap pendapatan berbagai pekerja pariwisata. Mereka harus berjuang untuk bertahan hidup di tengah kemelutnya perekonomian Bali. Dalam kondisi ini, para istri sebagai perempuan Bali harus ikut terlibat dalam pemertahanan ekonomi keluarga. Mereka berjuang melalui aktivitasnya di ranah publik sebagai pedagang makanan. Tulisan ini bertujuan untuk menjelaskan peran ganda perempuan khususnya istri pekerja pariwisata sebagai pemertahanan ekonomi keluarga selama pandemi serta implikasinya. Penelitian ini mencoba memberikan gambaran terkait studi gender di masa pandemi Covid-19 dengan menggunakan pendekatan peran perempuan dalam ranah domestik dan publik serta pendekatan studi subaltern untuk melihat implikasi dari fenomena beban ganda yang mereka alami. Penelitian ini dilakukan dengan teknik observasi, wawancara dan studi dokumen. Hasil kajian menunjukkan bahwa kelompok perempuan Bali ini sangat berperan dalam upaya ketahanan ekonomi keluarga di masa pandemi. Mereka menjadi solusi atas permasalahan ekonomi keluarga di masa pandemi melalui aktivitas membuka warung makanan untuk menutupi kebutuhan ekonomi keluarga mereka. Aktivitas mereka di ranah publik dilakukan tanpa meninggalkan kewajiban mereka di ranah domestik. Kondisi ini menjadikan istri pekerja pariwisata berperan ganda yang menempatkan mereka sebagai kelompok subaltern.
\end{abstract}

\section{Kata kunci: Peran Ganda, Perempuan Bali, Pandemi Covid-19}

\begin{abstract}
The Covid-19 pandemic affects the Balinese economy, which relies on the tourism sector. The decline in the level of tourist visits to Bali affects the income of various tourism workers. They have to struggle to survive in the middle of Bali's economic crisis. In this condition, the wives as Balinese women must be involved in maintaining the family economy. They struggle through their activities in the public sphere as food traders. This paper aims to explain the dual role of women, especially the wives of tourism workers, in maintaining the family economy during the pandemic and its implications. This study tries to provide an overview of gender studies during the Covid-19 pandemic by using an approach to the role of women in the domestic and public spheres as well as a subaltern study approach to see the implications of the double burden phenomenon they experience. This research was conducted by using observation, interview, and document study techniques. The results of the study show that this group of Balinese women plays a very important role in efforts to maintain family economic resilience during the pandemic. They are the solution to the family's economic problems during the pandemic through the activity of opening food stalls to cover the economic needs of their families. Their activities in the public sphere are carried out without leaving their obligations in the domestic sphere. This condition makes the wives of tourism workers have a dual role which places them as a subaltern group.
\end{abstract}

Keyword: Balinese Women, Doubel Burden, Pandemic Covid-19

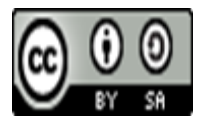

Received: October 20, 2020

Revised: June 10, 2021

Available Online: June 13, 2021

Jurnal Socius: Journal of Sociology Research and Education Vol. 8, No. 1, Th. 2021

ISSN: Online 2442-8663 - Print 2356-4180

Copyright $\odot 2021$, Jurnal Socius 


\section{Pendahuluan}

Virus Covid-19 yang pertama kali ditemukan di Kota Wuhan, Tiongkok pada akhir Tahun 2019 silam ini dengan sekejap merubah wajah dunia. Berbagai hingar bingar kehidupan dunia metropolitan segera meredup bahkan mati. Penyebaran yang begitu masif pada akhirnya menjangkiti berbagai negara di dunia. Virus yang menyerang sistem imunitas ini dengan segera menjadi fokus berbagai negara setelah WHO menetapkannya sebagai Pandemi Global pada pertengahan Maret 2020. Virus ini tidak hanya menyerang kesehatan manusia, namun juga menghadirkan efek domino yang luar biasa terhadap kehidupan manusia di seluruh belahan dunia. Indonesia sebagai negara di Asia tidak bisa terlepas dari serangan virus mematikan ini. Sejak diumumkannya kasus pertama Covid-19 pada awal Maret lalu, Indonesia mengalami guncangan yang luar biasa. Pandemi ini berdampak di berbagai sektor kehidupan masyarakat. Berbagai kebijakan diterbitkan untuk mencegah meluasnya penyebaran virus ini. Salah satu efek domino yang paling dirasakan di Indonesia adalah dampak ekonomi.

Industri pariwisata adalah sektor yang paling terdampak dalam pandemi ini, terutama Bali. Bali sebagai salah satu provinsi yang mengandalkan industri pariwisata dengan sekejap menjadi sepi pengunjung. Hingar bingar kehidupan malam di Kuta, hiruk pikuk wisatawan di Ubud, tari Kecak di Uluwatu seketika padam. Perekonomian Bali seolah ambruk diterjang virus yang tak kasat mata ini. LPEM FEB UI mencatat, tingkat okupansi atau hunian hotel di Bali mengalami penurunan drastis dari 63\% di bulan Desember 2019 menjadi 46\% di bulan Februari 2020 (LPEM-FEB-UI, 2020). Senior Associate Director Researh Colliers International Indonesia, Ferry Salanto seperti yang dikutip harianaceh.co.id menyatakan bahwa tingkat okupansi hotel di Bali mengalami fase terendah pada bulan Juli di angka 5\% dan belum menunjukkan tren positif sampai Agustus yang hanya naik tipis di angka 10\%. Bahkan perekonomian Bali sudah berada di ambang resesi pada Triwulan II yang menunjukkan angka $-7,22 \%$ (quarter-to-quarter) dan -10,98\% (year-to-year) (https://www.balipost.com, diakses pada 10 Oktober 2020). Mandetnya industri pariwisata Bali pada gilirannya akan merusak sendi-sendi ekonomi penduduknya yang sudah mulai dirasakan sampai ke desa-desa terpencil.

Menurunnya tingkat kunjungan wisatawan ke Bali pada akhirnya berdampak terhadap para pekerja pariwisata. Pemutusan hubungan kerja mulai menjamur di berbagai unit usaha yang menunjang industri pariwisata Bali seperti restauran, hotel, mal dan sebagainya. Perusahaan dengan terpaksa mengambil keputusan ini karena sudah tidak mampu menggaji karyawannya. Sebanyak 75 ribu pekerja terpaksa harus dirumahkan dan di PHK akibat menurunnya sektor perekonomian Bali (tirto.id, diakses pada 10 Oktober 2020). Sektor informal lain juga mengalami nasib yang sama seperti para sopir travel freelance, penjual cendera mata di jalan, para pemandu surfing bahkan juru parkir. Para pekerja sektor informal ini harus turut merasakan dahsyatnya gempuran Covid-19. Mereka harus memutar otak untuk menutupi kehidupan perekonomian keluarga setelah pandemi Covid-19. Istri mereka yang selama ini tidak bekerja dan mengandalkan pendapatan suami ikut berperan aktif dalam mencari celah-celah pendapatan lain. Para istri sebagai representasi perempuan Bali ini kemudian memilih untuk membuka usaha dagang untuk membantu perekonomian keluarga karena suami mereka sudah tidak memiliki penghasilan. Dengan menjadi pedagang kali lima, para kelompok istri ini berupaya mengumpulkan uang untuk kebutuhan ekonomi keluarga selama masa pandemi.

Secara konseptual, pedagang kali lima menurut Widjajanti (dalam Duwit, Kumurur, \& Moniaga, 2015) merupakan pedagang kecil yang berjualan di pinggir jalan seperti di taman, pinggir jalan raya, trotoar atau emperan toko tanpa memiliki ijin dari pemerintah. Sementara menurut Dorodjatun Kunjoro Jakti (dalam Budi, 2006) menjelaskan bahwa pedagang kaki lima merupakan bentuk aktivitas perdagangan sektor informal yang umumnya berperan sebagai penyalur barang-barang dan jasa ekonomi kota. Secara sederhana pedagang kaki lima dapat 
dipahami sebagai unit usaha kecil dengan modal yang relatif kecil yang melayani barang atau jasa yang dikonsumsi langsung oleh konsumen.

Setelah pandemi Covid-19 melanda, para istri pekerja sektor pariwisata Bali ini berinisiatif membantu ekonomi keluarga dengan kemampuan yang mereka miliki dengan membuka warung makanan. Meskipun mereka rata-rata tidak memiliki background sebagai pedagang, mereka tetap berusaha untuk menghidupi keluarga mereka. Turunnya tingkat perekonomian Bali yang sudah terasa sampai ke pelosok tidak mengurungkan niat para istri pekerja pariwisata ini untuk bekerja membantu perekonomian keluarga. Dukungan juga didapatkan dari para suami mengingat mereka sudah tidak bisa berbuat apa lagi. Dalam aktivitas pedagang kaki lima tersebut, para istri menjadi garda depan sementara suami hanya sebagai pendukung. Semua aktivitas perdagangan dilakukan oleh para istri sepenuhnya.

Seorang perempuan yang bekerja di ranah publik termasuk sebagai pedagang kaki lima tidak serta merta meninggalkan tugas dan kewajibannya di ranah domestik (Ismanto \& Suhartini, 2014). Mereka tetap melakukan aktivitas memasak, mengurus anak, mengurus rumah dan sebagainya. Kondisi ini mengantarkan mereka pada posisi beban ganda (double burden). Di satu sisi mereka harus berjuang di ranah publik untuk mendapatkan penghasilan, sementara tugas sebagai ibu tidak bisa digantikan oleh orang lain. Michele (dalam Hidayati, 2015) menyatakan bahwa beban ganda perempuan disebutnya sebagai dualisme kultural. Dualisme kultural yang dimaksud adalah keterlibatan perempuan dalam hal ini istri pekerja pariwisata Bali dalam public sphere dan domestic sphere. Mereka harus membantu perekonomian keluarga dengan berdagang di ranah publik dan juga berperan sebagai istri dan ibu di ranah domestik. Mereka harus menjalani aktivitas di kedua ranah tanpa mengabaikan salah satunya. Kondisi ini menunjukkan telah terjadi fenomena double burden pada para istri pekerja pariwisata asal Desa Bungkulan selama masa Pandemi Covid-19.

Tulisan bertujuan untuk mengkaji peran para perempuan Bali dalam hal ini istri pekerja pariwisata Bali asal Desa Bungkulan yang terkena dampak pandemi Covid-19 serta implikasinya terhadap posisi mereka dalam struktur masyarakat. Kajian ini berkontribusi dalam usaha memahami dahsyatnya dampak pandemi Covid-19 terhadap seluruh lapisan masyarakat, termasuk para istri pekerja pariwisata yang berjuang sebagai garda depan ketahanan ekonomi keluarga. Fenomena beban ganda perempuan terlebih di masa pandemi merupakan realitas empirik yang perlu dikaji dengan pendekatan sosial antropologis.

Dalam budaya patriarki, perempuan selalu diasosiasikan sebagai second sex yang dianggap lemah, tidak berdaya dan sebagainya (Barker, 2014). Meskipun perempuan kini mampu berada di ranah publik sebagai pekerja untuk menambah penghasilan keluarga, nyatanya mereka tidak bisa begitu saja meninggalkan kewajiban-kewajiban domestiknya. Kondisi inilah yang menyebabkan mereka mengalami beban ganda atau double burden. Hal ini disampaikan oleh Mila Karmilah dalam artikel yang berjudul 'Peran Ganda Perempuan di Lingkungan Pariwisata Bandungan Jawa Tengah'. Tulisan Karmilah menyoroti para pekerja perempuan di kawasan wisata Bandungan Kabupaten Semarang, Jawa Tengah. Hasil penelitiannya menunjukkan bahwa para perempuan yang bekerja dalam industri pariwisata merupakan sebuah strategi untuk menopang kehidupan ekonomi keluarga. Konsekuensinya adalah mereka harus menerima beban ganda sebagai ibu dan istri di rumah sekaligus sebagai pekerja di ranah publik (Karmilah, 2013). Kajian tersebut cukup relevan dengan penelitian ini, untuk melihat bagaimana kelompok perempuan Bali atau istri pekerja pariwisata Bali mengambil peran dalam ketahanan ekonomi keluarga di tengah Pandemi Covid-19.

Kajian-kajian sosial budaya mengenai dampak Pandemi Covid-19 mulai bermunculan belakangan ini. Kajian yang menggunakan perspektif sosial budaya penting dilakukan untuk melihat sejauh mana dampak pandemi terhadap kehidupan sosial masyarakat terlebih kelompok perempuan. Seperti yang dilakukan Indria Hapsari dalam artikelnya yang berjudul 'Konflik Peran Ganda dan Kesejahteraan Psikologis Pekerja yang mengalami work from home

Jurnal Socius: Journal of Sociology Research and Education Vol. 8, No. 1, Th. 2021 
selama Pandemi Covid-19'. Hapsari mencoba menelusuri pengaruh beban ganda pekerja yang mengalami work from home terhadap kondisi kesejahteraan psikologis pekerja melalui pendekatan ilmu psikologi. Hasil risetnya menunjukkan bahwa semakin tinggi konflik peran ganda yang dialami pekerja selama work from home, maka semakin rendah kesejahteraan psikologis para pekerja. Sebaliknya, semakin rendah konflik beban ganda yang dialami pekerja, semakin tinggi kesejahteraan psikologis yang dialami pekerja selama pandemi (Hapsari, 2020.). Temuan Hapsari bisa digunakan sebagai acuan dalam penelitian ini untuk melihat tingkat konfik beban ganda yang dialami istri pekerja selama pandemi serta korelasinya terhadap kondisi psikologis mereka.

Selama masa pandemi, perempuan dinilai beberapa kalangan bisa mengambil peran strategis dalam rangka menekan penyebaran virus Covid-19. Hal ini disampaikan Susilowati dalam artikelnya yang berjudul 'Optimalisasi Peran Perempuan sebagai Strategi Alternatif Kebijakan Publik dalam Menekan Penyebaran Pandemi Covid-19'. Susilowati menilai bahwa perempuan memiliki peranan cukup signifikan dalam upaya menekan penyebaran Covid-19. Pencegahan virus Covid-19 berbasis keluarga sebagai unit terkecil dalam tatanan bernegara dirasa cukup berpeluang dalam menekan angka penyebaran Covid-19. Melalui strategi bottom up, Susilowati merekomendasikan pemberdayaan perempuan dalam upaya menekan penyebaran Covid-19 dengan memberikan pengetahuan mendalam terkait virus mematikan ini (Susilowati \& Hakiem, 2020). Susilowati hanya melihat peran perempuan dalam aspek kesehatan keluarga dan mengabaikan peranan mereka terkait kondisi ekonomi akibat pandemi ini. Untuk itulah penelitian ini perlu dilakukan untuk melihat peran perempuan dalam aspek ekonomi pada masa pandemi.

Pandemi tidak hanya merisaukan bagi kelompok pekerja pariwisata saja, akan tetapi juga berdampak secara langsung pada kehidupan ekonomi mereka. Sementara, kelompok ibu rumah tangga yang selama ini berkecimpung dalam ranah domestik juga tidak lepas dari efek domino pandemi. Kehadiran pandemi memberikan beban tambahan kepada kelompok ibu Rumah Tangga yang cukup berpengaruh terhadap psikologis mereka. Komnas Perempuan dalam eksekutif summary yang berjudul 'Kajian Dinamika Perubahan di Dalam Rumah Tangga selama Covid-19 di 34 Provinsi' menjelaskan gejala yang demikian. Kajian ini menunjukkan bahwa kelompok istri atau ibu rumah tangga mengalami dampak khas selama pandemi. Beban pekerjaan yang mereka emban selama pandemi semakin meningkat berkenaan dengan sekolah daring yang menuntut mereka untuk hadir menjadi guru di rumah. Kajian ini juga menunjukkan bahwa telah terjadi kekerasan terutama kekerasan psikologis dan ekonomi terhadap kelompok istri selama pandemi. Kajian ini hanya terfokus terhadap beban tambahan yang diterima serta implikasinya terhadap kehidupan para istri selama pandemi (Komnas Perempuan, 2020). Kajian ini kurang tertarik melihat peranan perempuan dalam ketahanan ekonomi keluarga selama pandemi.

Kajian berikutnya yang digunakan adalah tulisan Ikfina Chairani yang berjudul 'Dampak Pandemi Covid-19 dalam Perspektif Gender di Indonesia'. Tulisan ini mencoba menguraikan dampak pandemi terhadap perempuan dalam aspek kesehatan, ekonomi dan kehidupan sosial. Hasil kajian Chairani menunjukkan bahwa selama masa pandemi akses kesehatan bagi perempuan sangat terbatas terutama terkait dengan proses persalinan. Secara ekonomi, perempuan menjadi sangat rentan karena dibayang-bayangi akan PHK serta tambahan beban dalam ranah domestik. Pandemi ini pada gilirannya berpotensi besar terhadap fenomena KDRT yang dialami perempuan (Chairani, 2020). Penelitian Chairani penting dijadikan acuan untuk melihat sejauh mana pandemi ini memberikan dampak terhadap kelompok perempuan termasuk kelompok istri pekerja pariwisata Bali dalam ketahanan ekonomi keluarga.

Pandemi ini memposisikan perempuan sebagai objek yang paling rentan terhadap berbagai efek dari pandemi tersebut. Secara sosial budaya, kiprah perempuan Indonesia dalam ranah publik maupun domestik menjadi daya topang kehidupan keluarga selama masa

Jurnal Socius: Journal of Sociology Research and Education Vol. 8, No. 1, Th. 2021 
pandemi. Hal ini disampaikan Titiek Nurhayati dalam artikelnya yang berjudul 'Emansipasi dalam Melawan Pandemi Global: Bukti dari Indonesia'. Nurhayati mencoba melihat bagaimana peran perempuan dalam ketahanan ekonomi keluarga selama masa pandemi. Nurhayati menilai perempuan Indonesia mampu hadir sebagai garda depan dalam ketahanan ekonomi keluarga melalui aktivitasnya baik di ranah domestik maupun publik sebagai upaya afirmasi ekonomi. Nurhayati melihat melalui dasar fiqih dalam ajaran Islam yang mampu memberikan ruang seluas-luasnya kepada perempuan dalam upaya ketahanan ekonomi keluarga selama pandemi (Nurhayati \& Halal, R, 2020). Nurhayati hanya menjelaskan kaidahkaidah keagamaan yang digunakan sebagai dasar emansipasi bagi kelompok perempuan. Penulis cenderung mengabaikan langkah konkret apa yang bisa dilakukan kelompok perempuan dalam rangka ketahanan ekonomi keluarga selama pandemi.

Berbagai literatur di atas menunjukkan bahwa perempuan merupakan sosok yang paling rentan terhadap dampak pandemi Covid-19. Bagi perempuan pekerja, mereka khawatir terhadap ancaman PHK yang bisa berpengaruh terhadap kehidupan ekonomi keluarga. Bagi perempuan yang hanya berkecimpung dalam ranah domestik, dengan beban tambahan yang mereka terima selama kebijakan sekolah daring yang ditetapkan pemerintah cenderung memperkuat upaya ketahanan ekonomi keluarga melalui aktivitas di ranah publik. Semangat ini ditunjukkan oleh beberapa istri pekerja pariwisata Bali yang berasal dari Banjar Dinas Badung, Desa Bungkulan dengan membuka usaha dagang. Mereka mengambil peran dalam upaya ketahanan ekonomi keluarga.

Perempuan Bali dikenal sebagai sosok yang kuat dan tangguh. Mereka mampu menjalani dan menjalankan berbagai peran dalam kehidupan adat, agama dan ekonomi. Hal ini disampaikan oleh Komalasari (2017) bahwa sikap pekerja keras dan ketangguhan perempuan Bali merupakan warisan masa lalu dalam budaya agraris yang menjadi penopang kehidupan masyarakat Bali. Lebih jauh Komalasari menilai bahwa perempuan Bali memiliki sumber daya yang mampu mengantarkan mereka berada pada dua ranah yakni ranah domestik dan ranah publik. Mereka masih bisa berkarya di luar rumah dan mampu melaksanakan kewajibannya dalam keluarga, adat dan agama secara lebih luas.

Kehadiran perempuan Bali sebagai penopang ekonomi selama pandemi ini bukanlah sesuatu yang baru di Bali. Mereka tetap menjalankan kewajiban sebagai istri dan ibu di kedua wilayah. Sebagai istri mereka tetap melakukan aktivitas memasak, mencuci, bersih-bersih dan sebagainya. Sebagai seorang ibu mereka tetap mencurahkan perhatian kepada anak terlebih sekolah daring yang diterapkan menuntut mereka untuk tetap mendampingi anak dalam proses belajar. Kondisi ini membawa perubahan yang cukup signifikan terhadap kehidupan para perempuan ini, sehingga peran ganda tidak bisa mereka hindari. Fenomena peran ganda atau double burden menurut Michele (dalam Hidayati, 2015) dijelaskan sebagai konsekuensi yang harus diterima perempuan ketika memutuskan untuk terjun ke ranah publik. Kondisi ini mengantarkan mereka pada posisi dualisme kultural yang mereka emban. Dualisme kultural yang dimaksud terkait dengan peran tradisi dan transisi perempuan. Peran tradisi adalah peranan perempuan dalam domestic sphere yang terkait dengan tugas dan kewajiban perempuan dalam rumah tangga. Sementara peran transisi terkait dengan partisipasi perempuan dalam public sphere sebagai pekerja, anggota masyarakat dan sebagai manusia pembangunan. Dengan melihat peran perempuan Bali sebagai istri pekerja pariwisata Bali dalam ranah domestik dan publik, akan ditemukan beban ganda yang mereka alami selama masa pandemi.

Implikasi dari peran ganda yang dialami perempuan akan dikaji secara kritis dengan pendekatan subaltern. Subaltern adalah konsep yang dipelopori oleh Gramsci (Barker, 2014) yang melihat bahwa dalam sebuah tatanan sosial akan selalu ditemukan kelompok-kelompok yang tidak terorganisir secara politis terlebih kelompok perempuan. Mereka diabaikan karena dianggap lemah dan tidak memiliki kekuatan untuk berbicara sehingga mengantarkan mereka pada posisi marginal. Proses marginalisasi ini terjadi akibat adanya kekuatan hegemoni yang

Jurnal Socius: Journal of Sociology Research and Education Vol. 8, No. 1, Th. 2021 
mengganggap mereka sebagai kelompok yang tidak penting dan tidak perlu didengarkan suaranya. Kekuatan ideologi tersebut bekerja secara laten dan dianggap sebagai sesuatu yang wajar. Ideologi tersebut seolah mendapatkan legitimasi dari anggota kelompok superior yang membuat kelompok subaltern semakin terpinggirkan. Penulis mengasumsikan bahwa beban ganda yang dialami kelompok istri pekerja pariwisata Bali yang menjadi garda depan ketahanan ekonomi keluarga di masa Pandemi Covid-19 mengantarkan mereka pada posisi subaltern yang terpinggirkan dan termarginalkan dalam tatanan sosial di masyarakat terlebih dalam tatanan budaya Bali yang kental akan budaya patriarki.

\section{Metode Penelitian}

Penelitian ini dilakukan dengan metode kualitatif dengan menerapkan model penelitian studi kasus (Koentjaraningrat, 2009). Pendekatan kualitatif dipilih mengingat penelitian ini menggunakan pendekatan sosial budaya dengan sumber data yang didominasi oleh penjelasan deskripsi naratif dan cenderung mengabaikan data dalam bentuk kuantitatif. Pengumpulan data dilakukan melalui proses wawancara dan pengamatan langsung atas berbagai gejala terkait fenomena peran perempuan Bali sebagai istri pekerja pariwisata di masa Pandemi. Pengumpulan data dilakukan dengan menyelami dan memahami kehidupan mereka. Peneliti melakukan pengamatan tanpa melakukan keterlibatan secara aktif. Pengamatan dilakukan pada keluarga pekerja pariwisata yang mana setelah Covid-19 istri bekerja di sektor publik. Fenomena yang diamati yaitu interaksi dalam keluarga antara istri, suami, anak-anak dan kerabat dekat mereka serta lingkungan masyarakat sekitar. Sikap suami terhadap istri, atau bahkan kerabat dekat terhadap istri yang bekerja di ranah publik, terutama setelah Covid-19.

Penulis mencoba melihat fenomena transformasi kelompok perempuan istri pekerja yang mengalami perubahan peran dari ranah domestik ke ranah publik. Meskipun banyak dijumpai perempuan Bali yang bekerja dalam dunia seni yang terkena dampak pandemi, perubahan yang mereka alami dirasa tidak begitu signifikan mengingat mereka sudah berada di ranah publik untuk bekerja sebelum pandemi. Subjek kajian dalam penelitian ini adalah kelompok perempuan istri pekerja pariwisata Bali yang berasal dari Banjar Dinas Badung, Desa Bungkulan, Kecamatan Sawan, Kabupaten Buleleng. Subjek ini dipilih karena para istri telah bertransformasi menjadi faktor penentu ketahanan ekonomi keluarga setelah para suami mereka terkena dampak ekonomi selama pandemi. Para perempuan ini sebelum masa pandemi merupakan ibu rumah tangga yang fokus mengurus kepentingan keluarga (domestik). Peran mereka mengalami perubahan yang signifikan dalam tatanan kehidupan keluarga mereka. Dalam kondisi pandemi seperti ini, para istri memilih membuka usaha dengan membuka warung kaki lima. Meskipun mereka bekerja dalam ranah publik, mereka tetap menjalankan kewajibannya di dalam ranah domestik. Dalam penelitian ini, unit analisis difokuskan pada tiga keluarga yakni keluarga Nyoman Srinasih yang memilih membuka warung nasi di Pedungan, Denpasar, Ketut Witarsih yang membuka warung klontong di depan rumahnya dan Komang Suryantini yang membuka usaha pisang keju dan minuman di jalan raya Desa Bungkulan. Mereka dipilih karena para suami tidak memiliki penghasilan selama pandemi dan usaha mereka satu-satunya sumber penghasilan sebagai upaya ketahanan ekonomi keluarga.

Jenis data yang dikumpulkan dan digunakan dalam penelitian ini adalah data kualitatif berupa uraian deskripsi kata-kata. Sumber data primer diperoleh melalui teknik observasi dan wawancara mendalam melalui wawancara secara langsung dengan informan (Goo, 2012). Proses pengamatan dan wawancara dilakukan pada awal Oktober 2020 dengan tetap menerapkan protokol kesehatan di masa Pandemi Covid-19. Sumber data sekunder yang digunakan dalam menunjang penelitian ini didapat melalui penerapan studi kepustakaan dengan menggunakan berbagai tinggalan berupa tulisan atau literatur yang terkait dengan topik penelitian (Nawawi, 2007). Informan dipilih melalui teknik purposive sampling dengan kriteria para istri pekerja pariwisata yang berperan dalam upaya meningkatkan ketahanan ekonomi 
keluarga di masa pandemi. Adapun informan lain yang dipilih adalah para suami dan keluarga dekat mereka. Peneliti merupakan instrumen utama dalam penelitian ini yang ditunjang dengan berbagai instrumen lain meliputi; pedoman wawancara, laptop, gawai (gadget) yang telah dilengkapi dengan fitur kamera, video dan perekam suara. Data disajikan secara deskriptif interpretatif melalui analisis data mengacu pada tiga tahapan yakni reduksi, penyajian dan verifikasi (Miles \& Huberman, 1989).

\section{Hasil dan Pembahasan}

\section{Profil Desa Bungkulan dan Potret Pekerja Pariwisata Bali}

Secara admisnistratif, Desa Bungkulan berada di bawah Pemerintahan Kecamatan Sawan, Kabupaten Buleleng, Provinsi Bali. Desa ini berada di punggung pulau Bali dengan toporgafi berupa pesisir dan didominasi dengan wilayah pertanian. Desa ini berada di ketinggian $7 \mathrm{mdpl}$ sehingga mata pencaharian penduduknya didominasi sebagai nelayan dan petani. Desa Bungkulan terdiri dari 13 Banjar Dinas yakni; Banjar Dinas Alas Harum, Ancak, Badung, Dauh Munduk, Jro Gusti, Jro Wargi, Kubu Kelod, Pamesan, Punduh Lo, Punduh Sangsit, Sari, Satria dan Sema. Desa Bungkulan terdiri dari dua Desa Pakraman atau desa adat yakni Desa Pakraman Bungkulan dan Desa Pakraman Sari Besikan. Jumlah penduduk pada tahun 2019 tercatat sebanyak 16.636 jiwa yang tersebar dalam 4.868 Kepala Keluarga (Profil Desa Bungkulan Tahun 2019).

Secara geografis Desa Bungkulan memiliki lahan yang cukup subur untuk wilayah pertanian seperti padi dan sayur-mayur. Sumber air yang digunakan untuk pengairan sawah berasal dari Tukad Daya yang melewati desa ini. Posisi desa yang berada di hilir dan dekat dengan pantai menyebabkan air tidak bisa menjangkau seluruh areal pertanian. Untuk menyiasatinya, petani memilih menggunakan sumber air sumur dengan bantuan mesin penyedot. Garis pantai yang cukup panjang menyebabkan beberapa warga memilih menjadi nelayan dengan membentuk kelompok-kelompok tersendiri. Hasil tangkapan nelayan biasanya berupa ikan cakalang, cumi dan ikan karang lain.

Kemajuan teknologi dan pendidikan yang dirasakan masyarakat Bungkulan menyebabkan kelompok pemudanya enggan berprofesi sebagai petani atau nelayan. Hanya sebagian kecil pemuda yang bersedia menggeluti profesi petani dan nelayan dan didominasi oleh pemuda yang memiliki tingkat pendidikan rendah. Para pemuda Desa Bungkulan lebih tertarik untuk bekerja di bidang pariwisata dan memutuskan untuk merantau ke wilayah Bali Selatan seperti Badung dan Denpasar. Ada semacam tradisi atau kebiasaan kelompok pemuda di Bungkulan terutama di Banjar Badung, setelah menyelesaikan pendidikan secara formal baik SLTA maupun perguruan tinggi, mereka akan memilih bekerja di industri pariwisata dan pendukungnya di wilayah Bali Selatan. Minimnya lapangan pekerjaan di Desa Bungkulan menyebabkan mereka memilih merantau ke luar kota. Para pekerja pariwisata yang berasal dari Banjar Badung, Desa Bungkulan didominasi sebagai sopir perjalanan wisata dan juru parkir. Profesi sopir travel terlebih yang bersifat freelance dipilih karena dirasa bisa menghasilkan pendapatan cukup besar. Sementara juru parkir dipilih karena adanya kedekatan salah seorang warga Banjar Badung dengan pemilik salah satu toko souvenir terkenal di Bali. Pemilik toko menyerahkan pengelolaan parkir kepada salah satu warga Banjar Badung yang kemudian merekrut keluarga dan warga lain sebagai juru parkir.

Pandemi Covid-19 berpengaruh negatif terhadap perekonomian para pekerja sopir travel dan juru parkir yang berasal dari Bajar Badung Desa Bungkulan. Berbagai aktivitas tour yang sudah dijadwalkan terpaksa dibatalkan karena pembatasan aktivitas warga selama pandemi. Menurunnya kedatangan wisatawan baik domestik maupun internasional menyebabkan para sopir travel dan juru parkir terpaksa dirumahkan. Pekerjaan yang tergolong dalam sektor informal dan tidak tercatat secara administrasi ini menjadi sektor yang paling terdampak

Jurnal Socius: Journal of Sociology Research and Education Vol. 8, No. 1, Th. 2021 
selama pandemi. Pendapatan harian yang mereka dapatkan seketika berhenti sehingga menuntut mereka untuk berupaya menutupi berbagai keperluan ekonomi keluarga.

Dalam kondisi ini, para perempuan Bali istri dari pekerja pariwisata Bali ini hadir sebagai faktor penentu ketahanan ekonomi keluarga. Mereka memilih membuka usaha warung makanan sebagai alernatif mendapatkan penghasilan. Fenomena ini ditunjukkan oleh Nyoman Srinasih (35 tahun), Ketut Witarsih (40 tahun) dan Komang Suryantini (30 tahun). Mereka adalah kelompok istri yang mengalami dampak luar biasa selama pandemi ini. Suami dari Nyoman Srinasih dan Komang Suryantini awalnya adalah pekerja sopir travel freelance. Sebelum pandemi hadir, mereka mengandalkan pendapatan suami sebagai sumber ekonomi keluarga. Dalam sehari perjalanan mereka bisa memperoleh penghasilan sejumlah Rp. 500.000,00 dari jasa yang ditawarkan. Pendapatan ini sudah mencukupi untuk keperluan keluarga sehingga para istri memilih untuk tidak bekerja dan fokus mengurus rumah tangga. Sementara suami dari Ketut Witarsih adalah seorang juru parkir di salah satu toko souvenir terkenal di wilayah Tuban, dekat dengan Bandara Ngurah Rai. Dalam sehari suami Witarsih bisa mengantongi pendapatan Rp. 200.000,00. Witarsih juga memilih fokus mengurus keluarga dan tidak bekerja karena pendapatan suami dirasa bisa mencukupi kebutuhan ekonomi mereka.

Pandemi Covid-19 yang hadir pada awal tahun ini berpengaruh pada penurunan pendapatan keluarga pekerja pariwisata Bali terutama yang berasal dari Banjar Dinas Badung, Bungkulan. Berbagai strategi dijalankan untuk menutup perekonomian keluarga. Minimnya pekerjaan di tengah masa pandemi menyebabkan keluarga ini memutuskan untuk beralih profesi dengan memberdayakan para istri yang memiliki keahlian dalam mengolah makanan. Para istripun kemudian membuka usaha dagang makanan sebagai strategi ketahanan ekonomi di masa pandemi. Para perempuan ini pada akhirnya berperan dalam sektor publik dengan dukungan para suami.

\section{Peran Istri Pekerja Pariwisata di Masa Pendemi}

Pandemi yang datang secara tiba-tiba mengubah kehidupan ekonomi para pekerja pariwisata Bali yang berasal dari Banjar Badung, Desa Bungkulan dalam sekejap. Minimnya tabungan yang mereka miliki membuat mereka berfikir mencari pendapatan lain. Untuk membantu perekonomian keluarga para istri memutuskan untuk membuka warung makanan yang sebelumnya tidak terpikirkan sama sekali. Pandemi ini hadir seolah merangsang kreativitas para perempuan dalam upaya ketahanan ekonomi keluarga. Srinasih memilih membuka warung makanan di Pedungan Denpasar pada awal Agustus silam. Warung makan ini dibuka di emperan mini market dengan sistem sewa. Warung makan khas Bungkulan ini buka dari pukul 17:00 sampai 22:00 malam. Target utama konsumennya adalah warga Buleleng dan warga sekitar Kelurahan Pedungan. Dalam sehari Srinasih bisa menghasilkan pendapatan sekitar Rp. 200.000 sampai Rp. 300.000 yang dirasa cukup untuk menutupi pengeluaran keluarga.

Suryantini yang sebelumnya tidak memiliki pengalaman sebagai pedagang harus bekerja keras untuk membantu perekonomian keluarga. Dia memilih membuka warung pisang keju dan aneka jus di pinggir jalan Desa Bungkulan. Dia menggunakan media sosial sebagai strategi marketing serta melayani delivery order. Penghasilannya dalam sehari antara Rp. 200.000 sampai Rp. 350.000. Sementara Witarsih memilih membuka warung kelontong di depan rumahnya yang berlokasi di Banjar Dinas Badung, Desa Bungkulan. Witarsih menjajakan tipat cantok, rujak dan aneka cemilan dengan target konsumen warga Banjar Badung. Melalui aktivitas niaga ini, Suryantini dan Witarsih mampu menutupi kebutuhan ekonomi selama pandemi. 


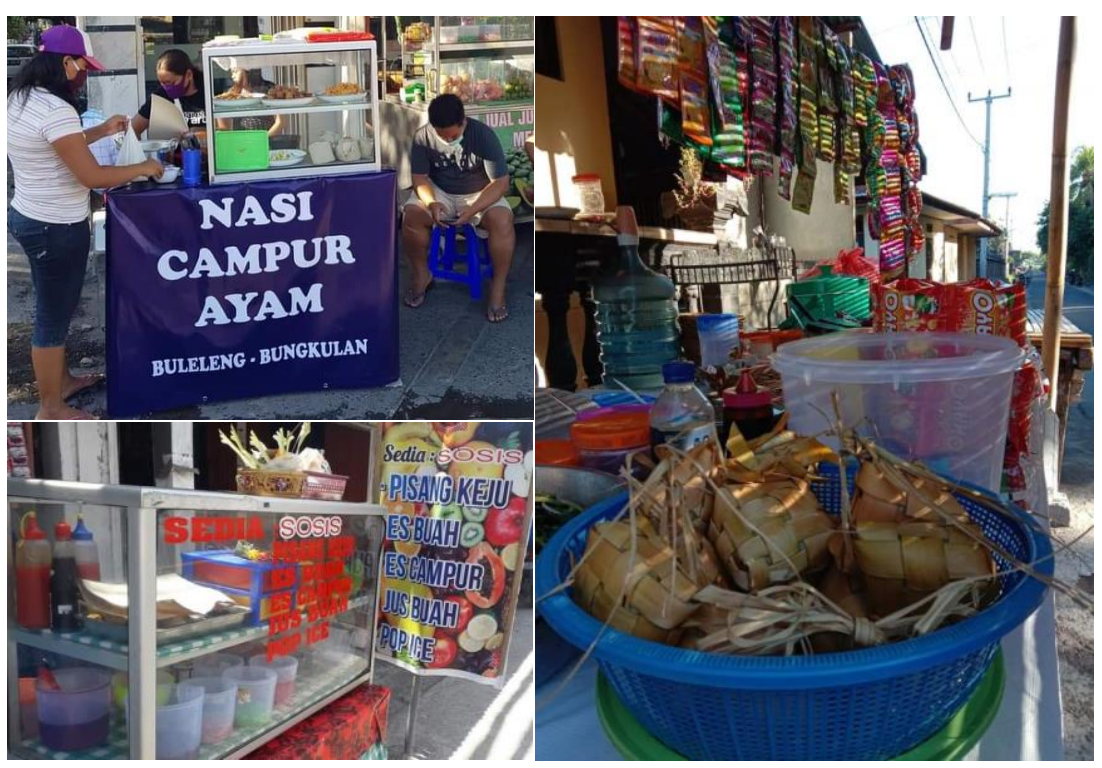

\section{Gambar 1. Warung Milik Srinasi, Suryantini dan Witarsih.}

Pandemi ini menuntut perempuan harus beraktivitas di ranah publik untuk membantu perekonomian keluarga. Mereka dituntut untuk bisa menjadi penopang perekonomian keluarga selama pandemi. Para istri pekerja pariwisata Bali yang awalnya hanya bekerja di ranah domestik terkait dengan pekerjaan rumah tangga, kini harus berpikir dan bekerja keras untuk mendapatkan penghasilan. Melemahnya perekonomian Bali tidak mengurangi aktivitas mereka untuk mendapatkan penghasilan. Dalam kondisi darurat seperti saat ini, perempuan memiliki peluang besar dalam upaya pemertahanan ekonomi keluarga melalui berbagai strategi. Hal ini senada dengan pernyataan Susilowati (2020) yang mengatakan bahwa perempuan Indonesia harusnya tampil sebagai penunjang dalam upaya ketahanan ekonomi keluarga melalui berbagai aktivitasnya baik di ranah domestik maupun publik. Strategi para istri pekerja pariwisata Bali di atas merupakan bukti keikutsertaan perempuan dalam menunjang perekonomian keluarga dalam situasi pandemi.

Transformasi dari domestic sphere menuju public sphere kelompok perempuan Bali ini dapat dipahami sebagai sebuah strategi adaptif mereka dalam upaya penyelamatan ekonomi keluarga. Kreativitas dan aktivitas mereka dituntut untuk dapat menghasilkan uang selama suami belum bisa beraktivitas dalam dunia pariwisata. Bourdieu (dalam Diana, 2017: 6) melihat strategi adaptif yang dipilih perempuan Bali istri pekerja pariwisata Bali dalam masa pandemi merupakan sebuah upaya penyesuaian diri terhadap kondisi yang sedang mereka dan keluarga alami. Menurut Bourdieu, habitus yang berada dalam pikiran mereka menyediakan berbagai skema yang terinternalisasi yang kemudian mereka gunakan untuk mempersepsi, memahami, mengapresiasi dan memahami dunia sosial. Kreativitas muncul dengan seketika ketika mereka mengalami kondisi kesulitan secara ekonomi. Berbagai pengalaman dan pengetahuan yang tersimpan dalam habitus mereka mulai bekerja dan diaktualisasikan melalui kreativitas mereka dalam usaha kuliner. "Kebetulan ibu saya dulu pedagang nasi, dari dulu saya sudah ingin buka usaha, namun suami melarang karena anak-anak masih kecil dan takut kelabakan. Dari kecil saya sudah bantu ibu jualan nasi dan tahu persis proses pengolahannya dari memasak sampai jualan" (Nyoman Srinasih, wawancara pada 10 Oktober 2020). Berbagai pengetahuan tersebut menjadi habitus Srinasih dan baru bisa diaktualisasikan setelah pandemi.

Pengetahuan dan pengalaman informan Suryantini juga menunjukkan gejala yang sama. "Saya memang hobi memasak. Sering saya bikin jajan seperti pisang goreng atau bolu untuk keluarga. Untuk pisang keju ini, saya hanya belajar otodidak melalui internet dan mencoba 
sendiri” (Komang Suryantini, wawancara pada 8 Oktober 2020). Pengetahuan-pengetahuan serta pengalaman yang telah tersimpan dalam alam pikir manusia atau dalam bahasanya Bourdieu disebut sebagai habitus sangat berguna bagi Suryantini ditambah dengan pengetahuan yang ia dapatkan dalam dunia internet. Pengalaman berbeda ditunjukkan oleh Ketut Witarsih. "Saya suka masak tapi jarang sekali membuat tipat cantok. Kalau urusan rujak, sudah sering saya bikin sebelum buka usaha ini. Kebetulan keluarga besar saya suka rujak, dan saya yang selalu diminta untuk membuatkan" (Ketut Witarsih, wawancara pada 9 Oktober 2020). Berdasarkan informasi di atas terlihat bahwa Witarsih sudah berpengalaman sehingga tidak begitu mengalami kesulitan untuk membuka usaha warung. Pengalaman serta pengetahuan para perempuan Bali ini bermanfaat dalam situasi pandemi. Pengetahuan tentang kuliner Bali tidak terlepas dari pengalaman yang dimiliki dalam menjalankan tugasnya di ranah domestik sebelum pandemi.

Berdasarkan deskripsi di atas dapat dipahami bahwa kreativitas yang bersumber dari habitus para perempuan ini sangat bermanfaat dalam upaya kebertahanan ekonomi keluarga. Selama pandemi usaha yang mereka jalani bisa menutupi kebutuhan keluarga sehingga mereka bertahan sampai saat ini. Para perempuan Bali ini berperan disektor publik ketika suami mereka tidak bekerja karena terdampak Covid-19. Hal ini senada dengan pandangan Nurhayati (2020) yang menyatakan bahwa dalam masa pandemi sangat dibutuhkan peran afirmatif perempuan dalam kehidupan ekonomi keluarga. Ketahanan ekonomi keluarga merupakan tanggung jawab bersama antara laki-laki (suami) dan perempuan (istri).

Peran perempuan tidak selalu dalam bidang domestik, tetapi juga di sektor publik. Semakin sempitnya ranah publik yang diakses kelompok suami selama pandemi, menyebabkan perempuan harus berkontribusi di ranah publik sebagai perwujudan kesetaraan gender. Relasi kerjasama terwujud sebagai implikasi dari keputusan bersama untuk membangun usaha berdagang. Dalam prakteknya ditemukan relasi kerjasama antar kedua gender melalui pembagian kerja dimana kelompok suami berperan dalam aktivitas yang membutuhkan tenaga besar seperti mengangkut barang dagangan, menata dagangan dan sebagainya, sementara perempuan tampil dalam aktivitas yang tidak membutuhkan tenaga besar seperti melayani konsumen, menjaga warung dan sebagainya. Relasi kerjasama ini juga terlihat dalam aktivitas domestik mereka. Pada saat para istri berada di warung untuk melayani konsumen, para suamilah yang bersiaga untuk menyelesaikan aktivitas domestik seperti mengurus anak, membersihkan rumah dan sebagainya. Bentuk relasi gender ini cukup ideal dalam perwujudan relasi gender yang sehat dan adil meskipun dalam beberapa kesempatan mengalami berbagai kendala.

\section{Implikasi Pandemi Covid-19 terhadap Kehidupan Istri Pekerja Pariwisata}

Keberadaan perempuan di sektor publik sebagai upaya ketahanan ekonomi keluarga berdampak pada mereka. Keputusan perempuan untuk berperan di ranah publik tidak membebaskan peran mereka di sektor domestik. Mereka tetap melakukan aktivitasnya di ranah domestik seperti memasak, mencuci, mengurus anak dan pekerjaan rumah tangga lainnya. Partisipasi mereka dalam public sphere sebagai tulang punggung keluarga berimplikasi terhadap posisi peran ganda (double burden).

Posisi peran ganda ini dalam bahasanya Michele (dalam Hidayati, 2015)) dijelaskan sebagai partisipasi aktif perempuan dalam ranah tradisi dan transisi. Pada ranah tradisi mereka tidak bisa melepaskan tanggung jawabnya dalam ranah domestik sebagai ibu rumah tangga. "Pagi saya ke pasar untuk membeli keperluan dagangan sekaligus keperluan keluarga, sehabis itu masak dan beres-beres rumah, jam 8 pagi buka warung" (Ketut Witarsih). Hal senada juga disampaikan oleh Suryantini, "Saya selesaikan terlebih dahulu urusan rumah, memberi makan anak-anak, memandikannya sampai benar-benar selesai urusan rumah, selanjutnya saya buka warung bersama suami”.

Jurnal Socius: Journal of Sociology Research and Education Vol. 8, No. 1, Th. 2021 
Meskipun mereka telah memposisikan diri di sektor publik, mereka masih tetap mejalankan tanggung jawabnya di rumah. Mereka berada di kedua ranah tanpa bisa mengabaikan salah satunya. Keputusan sekolah daring yang diterapkan pemerintah semakin menambah beban yang mereka emban selama pandemi. Selain aspek ekonomi, perempuan juga bertanggungjawab terhadap pendidikan anak karena pandemi. Mereka harus tetap memperhatikan berbagai aktivitas sekolah daring anak-anak mereka. "Saya selalu menyempatkan menemani anak untuk mengerjakan tugas-tugas sekolahnya, diwaktu siang selesai memasak untuk jualan, saya harus menyelesaikan tugas anak seperti mengirim foto atau video aktivitas anak belajar di rumah" (Nyoman Srinasih). Srinasih yang memiliki anak kelas 1 SD dituntut untuk selalu menemani anak dalam mengerjakan tugas-tugas sekolah yang diberikan oleh guru mereka. Pendidikan anak menjadi tanggung jawab mutlak ibu dan tidak bisa digantikan oleh siapapun termasuk bapak. "Saya yang ngajarin anak waktu di rumah. Kalau bapaknya kurang sabar waktu ngajarin anak sehingga anak saya lebih nyaman kalau saya yang ngajarin" (Ketut Witarsih). Peran semacam ini tidak bisa digantikan oleh siapapun termasuk bapak karena mereka (ibu) memiliki sikap lembut dan sabar sehingga anak lebih memilih ibu untuk mengajari mereka ketimbang bapak.

Posisi peran ganda perempuan para istri pekerja pariwisata di Bali ini pada gilirannya akan mempengaruhi psikologis mereka. Dalam satu waktu mereka harus memikirkan ekonomi keluarga, pendidikan anak, tanggung jawab rumah tangga serta urusan kesehatan terkait Virus Corona. Beban itu semakin berat ditambah dengan kewajiban-kewajiban mereka dalam urusan keagamaan. Pada saat perayaan hari raya Galungan dan Kuningan pada bulan September silam misalnya, mereka juga harus mempersiapkan berbagai sarana upacara seorang diri sehingga menambah pekerjaan mereka, mulai darimengurus dagangan, pendidikan anak, makanan hingga ritual keagamaan.

Peran ganda yang dilakoni para istri pekerja pariwisata Bali asal Banjar Badung Desa Bungkulan ini pada gilirannya memposisikan mereka sebagai kelompok subaltern. Mereka kemudian termarginalkan dan terpinggirkan dalam struktur sosial masyarakat. Gramsci (dalam Suryawan 2010,82) melihat bahwa posisi subaltern yang dialami kelompok tertentu tak bisa lepas dari kekuatan-kekuatan hegemoni ideologi tertentu. Kuatnya ideologi patriarki di Bali yang memposisikan perempuan sebagai the second sex telah menuntun para perempuan ini ke kondisi subaltern. Seperti penjelasan Ariyanti dan Ardhana (2002) bahwa budaya patriarki di Bali menjadi salah satu alasan terjadinya kekerasan terhadap perempuan baik secara fisik maupun verbal (Ariyanti, Putri, \& Ardhana, 2020). Kekerasan ini pada gilirannya akan mempengaruhi psikologis perempuan Bali seperti rasa cemas, khawatir, pikiran negatif tentang diri, perasaan tidak berharga dan sebagainya.

Kondisi peran ganda yang dialami para istri pekerja pariwisata ini terlebih di masa pandemi merupakan salah satu bentuk ketidakadilan gender. Seperti yang dijelaskan oleh Hidayati (2015) bahwa posisi beban ganda yang dialami perempuan yang memilih beraktivitas di ranah publik merupakan bentuk ketidakadilan gender. Mereka harus berjuang di ranah publik untuk menyelamatkan ekonomi keluarga sementara mereka masih terikat oleh mitos-mitos patriarki. Mereka masih tetap sebagai the second sex di balik bayang-bayang laki di belakangnya.

\section{Simpulan}

Berdasarkan pembahasan di atas dapat disimpulkan bahwa selama masa pandemi Covid19, perempuan Bali istri pekerja pariwisata yang terkena dampak Covid-19 berperan penting dalam upaya ketahanan ekonomi keluarga. Mereka berupaya berkreativitas di ranah publik untuk membantu perekonomian keluarga tanpa meninggalkan tugas dan tanggung jawabnya di ranah domestik. Mereka terus berjuang untuk menyelesaikan tugas selama pandemi. Aktivitas di ranah publik melalui usaha dagang tanpa meninggalkan kewajiban sebagai ibu rumah tangga 
mengantarkan mereka pada posisi peran ganda (double burden). Posisi ini pada gilirannya menempatkan mereka sebagai kelompok subaltern di tengah kuatnya hegemoni budaya patriarki pada masyarakat Bali.

\section{Daftar Pustaka}

Ariyanti, A., Putri, N. M., \& Ardhana, I. K. (2020). Dampak Psikologis Kekerasan dalam Rumah Tangga terhadap Perempuan pada Budaya Patriarki di Bali. Jurnal Kajian Bali (Journal of Bali Studies), 10(1), 283-304.

Barker, C. (2014). Kamus Kajian Budaya. Yogyakarta: PT Kanisius.

Budi, A. S. (2006). Kajian Lokasi Pedagang Kaki Lima Berdasarkan Preferensi PKL Serta Persepsi Masyarakat Sekitar di Kota Malang. Universitas Diponegoro.

Chairani, I. (2020). Dampak Pandemi Covid-19 Dalam Perspektif Gender di Indonesia. Jurnal Kependudukan Indonesia, 14(2), 39-42.

Duwit, B. S., Kumurur, V. A., \& Moniaga, I. L. (2015). Persepsi Pedagang Kaki Lima Terhadap Area Berjualan Sepanjang Jalan Pasar Pinasungkan Karombasan Manado. Sabua, 7(2), 419-427.

Goo, A. A. (2012). Kamus Antropologi. Jayapura: Lembaga Studi Meeologi Makeewaapa Papua.

Hapsari, I. (2020). Psikologis Pekerja Yang Menjalani Work From Home Selama Pandemi Covid-19. Jurnal Psikologi, 13(1), 37-45.

Hidayati, N. (2015). Beban Ganda Perempuan Bekerja (Antara Domestik dan Publik). Muwazah, 7(2), 108-119.

Ismanto, A., \& Suhartini, E. (2014). Beban Ganda Wanita Karir di PT . PJB Up Paiton. Artikel Ilmiah Hasil Penelitian Mahasiswa, 1(1), 1-5.

Karmilah, M. (2013). Peran Ganda Perempuan di Lingkungan Pariwisata Bandungan Jawa Tengah. Palastren: Jurnal Studi Gender, 6(1), 129-158.

Koentjaraningrat, K. (2009). Pengantar Ilmu Antropologi. Jakarta: Rineka Cipta.

Komnas Perempuan. (2020). Kajian Dinamika Perubahan di Dalam Rumah Tangga Selama Covid 19 di 34 Provinsi di Indonesia. Retrieved from komnasperempuan.go.id

LPEM-FEB-UI. (2020). Dampak Pandemi Covid-19 terhadap Pariwisata Indonesia: Tantangan, Outlook dan Respon Kebijakan. Retrieved from https://www.lpem.org/wpcontent/uploads/2020/04/Briefing-Note-Dampak-Pandemi-Covid-19-terhadapPariwisata-LPEM-UI-April-2020.pdf

Miles, \& Huberman. (1989). Qualitative Data Analysis. England: Sage Publications.

Nawawi, H. H. (2007). Metode Penelitian Bidang Sosial. Yogyakarta: Gadjah Mada University Press.

Nurhayati, T., \& Halal, R, S. A. (2020). Emansipasi Melawan Pandemi Global ; Bukti Dari Indonesia. Jurnal Adalah: Buletin Hukum Dan Keadilan, 4(1), 81-92.

Susilowati, I., \& Hakiem, F. N. (2020). Optimalisasi Peran Perempuan Sebagai Strategi Alternatif Kebijakan Publik Dalam Menekan Penyebaran Pandemi Covid-19. SALAM: Jurnal Sosial Dan Budaya Syar-I, 7(8), 723-736. https://doi.org/10.15408/sjsbs. v7i8.16551 